\title{
Fish assemblage patterns as a tool to aid conservation in the Olifants River catchment (East), South Africa
}

\author{
Brenda Rashleigh ${ }^{1 *}$, Devlyn Hardwick ${ }^{2}$ and Dirk Roux ${ }^{3}$ \\ ${ }^{1}$ US Environmental Protection Agency, 960 College Station Road, Athens, GA 30605, USA \\ ${ }^{2}$ University of Witwatersrand, Private Bag 3, Wits 2050, South Africa \\ ${ }^{3}$ Monash University (South African Campus), Private Bag X60, Roodepoort 1725, South Africa
}

\begin{abstract}
South Africa has committed to address freshwater conservation at the catchment scale, using a combination of landscapelevel and species-level features as surrogates of freshwater biodiversity. To support this work, we examined fishes in the Olifants River catchment, where multiple anthropogenic pressures affect streams. Patterns in fish assemblage data across 88 sites were analysed and related to landscape environmental variables using statistical techniques of multivariate ordination, cluster analysis, and regression tree analysis. We identified 6 distinct fish assemblage types, which were separated by altitude and human influence, primarily dry-land cropping and dams. In the upper reaches of the catchment, we identified a faunal shift from Barbus neefi, which occurred in less impacted sites, to B. anoplus and Tilapia sparrmanii, which were favored in cropland and mixed cropland/urban settings, respectively. The fish assemblage of the middle section of the catchment was not unique, but supported one species, Chiloglanis pretoriae, that could be considered a focal species for conservation. The low altitude, high-runoff section of the catchment supported the most species. However, species richness increased in association with dams, through the addition of species that are more tolerant of flow and physicochemical modifications. Thus, species richness may not be an optimal conservation target for this system. Rather, a series of indicators will be necessary to track and measure conservation success in the Olifants catchment.
\end{abstract}

Keywords: focal species, dams, species richness, land use, conservation planning

\section{Introduction}

The freshwater ichthyofauna of South Africa is currently threatened by several factors, not least of which include development, water withdrawal, domestic and industrial effluents, and agricultural pollution (Ashton, 2007). Skelton et al. (1995) noted that there is limited scope for fish conservation within formally or informally delineated reserves, so the survival of the fauna depends largely on the success of conservation efforts outside protected areas. In the multi-use environment of water resources, overlapping and sometimes conflicting policy mandates from different service sectors hinders effective freshwater conservation; successful conservation efforts require policy alignment and cooperation across these sectors (Roux et al., 2006).

Freshwater conservation planning often involves a spatially nested approach (Higgins et al. 2005). The largest scale would be global conservation priorities developed by organisations such as World Wildlife Fund and the International Union for Conservation of Nature (IUCN). More targeted approaches for South Africa would be a national spatial biodiversity assessment (Nel et al., 2007), and sub-national assessment such as Roux et al. (2008). Larger scales are coarser, and some conservation features that are missed at this scale need to be considered at a lower scale. Within South Africa, there are 19 designated Water Management Areas (WMA); the water

\footnotetext{
* To whom all correspondence should be addressed.

Alternative address: University of the Witwatersrand, School of

Geography, Archaeology and Environmental Studies, Private Bag 3 , Wits 2050, South Africa

욜 +11 706-355-8148; fax: +11 706-355-8104; e-mail: Rashleigh.Brenda@epa.gov

Received 22 December 2008; accepted in revised form 25 April 2009.
}

resources within a WMA are managed by a Catchment Management Agency through Catchment Management Strategies (Pollard et al., 2007). Catchments are arguably the lowest scale, and also the scale where conservation plans and operational actions meet. Roux et al. (2006) suggested that the catchment is the appropriate scale for the implementation of national conservation targets in South Africa.

Within a catchment, fish conservation may consider the full suite of species that occur there. Managers often focus on species diversity, and target areas of high diversity within a catchment for conservation (Lévêque, 1997). Conservation efforts may also consider the structure of the fish assemblage. For example, Ibanez et al. (2007) noted that it is important to identify distinct assemblages in river systems, so that each can be explicitly integrated into conservation plans. It is also important to understand how both natural biogeography and anthropogenic alterations influence assemblages (Matthews, 1998). Roux et al. (2002) noted that under certain environmental conditions, a river ecosystem may be transformed to the extent that a new equilibrium assemblage occurs. For example, Langdon (2001) identified a switch from brook troutand sculpin-dominated assemblages to minnow-dominated assemblages with increasing degradation in coldwater streams in Vermont, USA. In some cases, such shifts in the assemblage may not be reversible (Beisner et al., 2003).

An alternative conservation approach is the use of individual species as endpoints. Single species approaches may focus on a species of concern such as an endemic or endangered species. Focal species, which are particularly sensitive to environmental disturbance or limited in their habitat needs, and umbrella species, whose habitat needs overlap with many other species, may also be conservation targets (Cato and O'Doherty, 1999; Abell, 2002). For instance, conservation management 


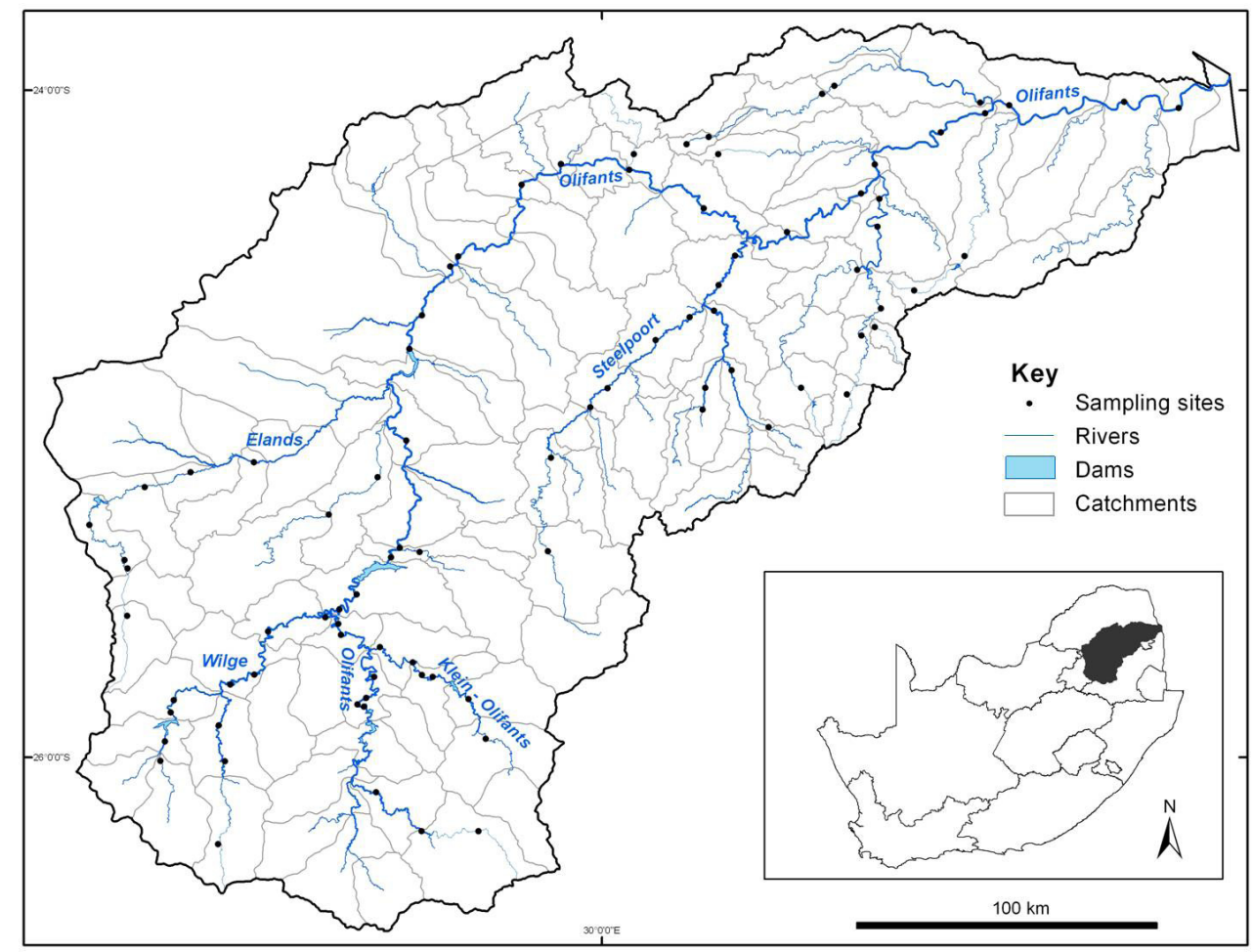

Figure 1

Map of the Olifants (East) River

catchment, within South Africa (inset). Sampling locations are shown as points on the map.

activities in South Africa often target focal species based on their regional endemism or specialised environmental requirements (Roux et al., 2008). Similarly, Rivers-Moore et al. (2007) noted that current research priorities for freshwater conservation in the KwaZulu-Natal Province include developing a list of freshwater umbrella species, whose distribution ranges will need to be modelled.

We investigated patterns in freshwater fish assemblages in the Olifants River (East) catchment, one of the 19 designated South African Water Management Areas (WMA) within South Africa (Pollard et al., 2007). The catchment represents a natural unit for conservation in terms of population structure and evolutionary history of lotic organisms (Wishart, 2000). Although the riverine ecology of the Olifants has not been analysed as extensively as the nearby Crocodile and the Sabie Rivers (e.g. Jewitt et al., 1998), high-quality data are available for this catchment through the National River Health Programme (Dallas et al., 2007). Aquatic biodiversity in the lower part of the catchment has been analysed in the context of the biodiversity of Kruger National Park (Roux et al., 2008), but the aquatic ecology of the catchment has not been studied extensively in toto.

Our objectives were to analyse patterns within the fish assemblages in the Olifants, to better understand the natural and anthropogenic influences on these fish assemblages and to identify conservation priorities for the catchment. Both species and assemblage patterns are important in this effort, and may be synergistic (Lindenmayer et al., 2007). For example, assemblage level studies can identify areas where detailed single species information is required while gaining general information about many species, and species-level work can yield detailed understanding of species-environment relationships that may drive assemblage level patterns. Ultimately, this work should provide insight appropriate to conservation and management policies, and help to restore and improve biotic integrity in this system (Novotny et al., 2005).

\section{Methods}

\section{Study area}

The Olifants catchment is part of the Zambezian Lowland aquatic eco-region, which supports naturally high fish diversity due to the mixing of tropical and southern temperate faunas (Skelton et al., 1995). This region supports 124 fish species, most of which are cichlids, cyprinids, gobies, and mochokid catfishes (Thieme et al., 2005). The Olifants River catchment encompasses about $54500 \mathrm{~km}^{2}$ in north-eastern South Africa (Fig. 1). The Olifants River originates east of Johannesburg, and flows north-east to the Kruger National Park, then into Mozambique and the Massingire Dam, and ultimately drains into the Indian Ocean. The river flows through several ecoregions, from the Highveld grasslands, through the central highlands and great escarpment mountains, to the Lowveld (WRC, 2001). The mean annual rainfall ranges from 500 to $1000 \mathrm{~mm}$ and is strongly seasonal, occurring mainly during the summer months of October through March (DWAF, 2004). The upper portion of the catchment is influenced by agriculture, mining, small dams, and alien vegetation and fauna, while the major downstream pressures are water and sediment releases from large storage dams (WRC, 2001). The WRC (2001) noted that rivers in the catchment are generally in poor to fair condition; selected tributaries in the middle of the catchment and protected areas in Kruger National Park are mostly in fair to good condition.

\section{Data}

Fish data were provided by the DWAF River Health Programme (Dallas et al., 2007). This database included 88 sites in the Olifants catchment (Fig. 1). All the samples were collected from 1998-1999, except one which was collected in 2004. These data were collected using an electrical shocker for 
TABLE 1

Environmental variables used in analysis. Axis 1, Axis 2: Spearman correlation coefficients for variables that are correlated $(p<0.05)$ with ordination axes (Fig. 3$)$

\begin{tabular}{|c|c|c|c|c|c|c|c|}
\hline Variable (units) & Code & Mean & SD & Min & Max & Axis 1 & Axis 2 \\
\hline \multicolumn{8}{|l|}{ Land use $(\%)$} \\
\hline Protected area & pProt & 17 & 28 & 0 & 100 & 0.27 & \\
\hline Irrigated agriculture & pAgr & 3 & 4 & 0 & 18 & & \\
\hline Dry-land cropping & pCrop & 13 & 15 & 0 & 52 & -0.40 & -0.37 \\
\hline Plantation & pPlan & 2 & 8 & 0 & 60 & -0.41 & \\
\hline Urban and Industry & $\mathrm{pUrb}$ & 3 & 3 & 0 & 11 & & $-\overline{0.24}$ \\
\hline Natural & pNat & 73 & 20 & 18 & 100 & 0.22 & 0.21 \\
\hline Altitude (m) & Altitude & 972 & 370 & 200 & 1600 & -0.70 & \\
\hline Watershed area $\left(\mathrm{km}^{2}\right)$ & Area & 526 & 435 & 79 & 2927 & & \\
\hline Number of active mines (\#) & Mines & 0.6 & 1.3 & 0 & 6 & & \\
\hline Constructed water-bodies (dams/weirs) (\#) & Dams & 1.0 & 1.6 & 0 & 9 & -0.35 & -0.32 \\
\hline Road and rail crossings on main stem (\#) & $\mathrm{RRCr}$ & 5.1 & 4.3 & 0 & 17 & -0.44 & \\
\hline Exports via Inter-Basin Transfers $\left(\mathrm{Mm}^{3} / \mathrm{a}\right)$ & IBT & 2.1 & 8.2 & 0 & 50.1 & & \\
\hline Annual runoff $\left(\mathrm{Mm}^{3} / \mathrm{a}\right)$ & Runoff & 34 & 52 & -5 & 252 & 0.39 & \\
\hline Dam: Runoff ratio (\%) & Drratio & 1.3 & 5.4 & 0 & 48 & & -0.36 \\
\hline
\end{tabular}

most habitats, supplemented with a seine net for deep habitats (Kleynhans, 2008). Raw abundance data were available for all samples, and shallow and deep water samples were combined for our analysis. Environmental variables used in this analysis were compiled using ARC/INFO Geographic Information Systems (GIS) (Table 1). These data include land use and landscape features of transportation, mines, and constructed areas, as well as three hydrologic measures: annual runoff in $\mathrm{Mm}^{3} / \mathrm{a}$ (million cubic meters per annum), the net amount of water transferred out of the basin, and dam:runoff ratio, which is the full storage capacity of a drainage $\left(\mathrm{Mm}^{3}\right)$ divided by the annual runoff.

\section{Analysis}

First, we examined patterns in species richness, using a regression tree to relate richness to thresholds of selected environmental variables. In the tree structure, 'leaves' represent classifications and 'branches' represent conjunctions of features that lead to those classifications. Trees were developed with recursive partitioning, a non-parametric technique, in the $\mathrm{R}$ software (version 2.9.0) using the rpart package (Therneau and Atkinson, 2008). The trees for these species were 'pruned' at the level of minimum error (McCune et al., 2002).

Next, we examined assemblage structure using ordination of the fish assemblage data. Ordination was conducted with non-metric multidimensional scaling (NMS), using $\log (\mathrm{n}+1)$ transformed fish abundance data, a random starting configuration, and the Sørensen's distance measure; species occurring at $<3$ sites were dropped, since rare species can reduce pattern detection (McCune et al., 2002). Spearman correlation analysis in the SAS statistical package (www.sas.com) was used to relate environmental variables to site scores along the 2 NMS axes that explained the most variation in the fish assemblage data. We used hierarchical cluster analysis to identify groups of sites with similar fish assemblages (Euclidean distance, Wards linkage). The nonparametric Multi-Response Permutation Procedures (MRPP) Method was then used to test the significance of the clustering results. MRPP is a non-parametric test of the null hypothesis that no differences occur among pre-defined groups. NMS, cluster analysis, and MRPP were conducted using PC-ORD statistical software (Version 4.0, McCune and Medford, 1999).

Finally, we considered patterns for individual species. We used indicator species analysis in PC-ORD to identify fish species that were significantly associated with particular site clusters. Indicator species analysis uses the distribution and abundance of each species to determine a species-specific indicator value (IV) that is compared with estimates from 1000 randomised Monte Carlo simulations to test its significance. Indicator selection was based on the criteria of Dufrêne and Legendre (1997), who define indicators as species with an IV $>25 \%$ and Monte Carlo test significance of $p<0.05$. For each indicator species, we developed classification trees to relate species occurrence to thresholds of the environmental variables identified as significant in our earlier analysis. Classification trees were developed in a manner similar to the regression tree described above, but the response variable in a classification tree is presence (' 1 ') or absence (' 0 '). We further interpreted our species-level results using Kleynhans (2008) ratings for species tolerance to modifications in flow and physicochemical conditions; ratings range from 0 (tolerant) to 5 (intolerant, see Table 2).

\section{Results}

A total of 42 fish species were collected from sites previously surveyed in the Olifants catchment. Species richness ranged from 1 to 18 , with a mean of 6.3 species. The initial split in our regression tree for species richness (Fig. 2) showed that higher fish species richness occurred at lower altitude $(<875 \mathrm{~m})$. For higher altitude sites (Fig. 2, left branch), the next split was based on runoff - higher species richness was associated with greater runoff. For low-altitude sites (Fig. 2, right branch), species richness was higher in sites with higher water runoff ( $>87.1 \mathrm{Mm}^{3} / \mathrm{a}$, Split 2). For sites with lower water runoff, richness was higher for a higher dam: runoff ratio (Split 3). That is, more species occur when more of the water is dammed.

In order to examine the assemblage in further analysis, we dropped rare species. Eight species, namely Barbus toppini (East-coast barb), Gambusia affinis (mosquitofish), Glossogobius callidus (river goby), Glossogobius giuris (tank 


\section{TABLE 2}

Fish species occurring at $>2$ sites in the Olifants River catchment $\left({ }^{*}=\right.$ selected as focal species by Roux et al., 2008).

Fauna: Z=Zambezian, ST=southern temperate, E=endemic to South Africa (from Skelton, 1993).

Dist.: Percentage of sites in catchment where the species occurs. Flw, PC: Tolerance to modifications of flow and physicochemical conditions, ranging from 0 (tolerant) to 5 (intolerant) (Kleynhans, 2008). Grp: site group for which the species is an indicator (see Fig. 3).

\begin{tabular}{|c|c|c|c|c|c|c|c|c|}
\hline Code & Scientific name & Common name & Family & Fauna & Dist & FIw & PC & Grp \\
\hline Macu & Micralestes acutidens (Peters, 1852) & silver robber & Alestidae & Z & 13 & 3.1 & 3.1 & $\mathrm{~F}$ \\
\hline Bann & Barbus annectens (Gilchrist \& Thompson, 1917) & broadstriped barb & Cyprinidae & $\mathrm{Z}$ & 9 & 2.8 & 3 & $\mathrm{~F}$ \\
\hline Bano & Barbus anoplus (Weber; 1897) & chubbyhead barb & Cyprinidae & $\mathrm{ST} / \mathrm{E}$ & 22 & 2.3 & 2.6 & A \\
\hline Beut & Barbus eutaenia (Boulenger, 1904) & orangefin barb & Cyprinidae & $\mathrm{Z}$ & 10 & 4.6 & 4.9 & \\
\hline Blin & Barbus lineomaculatus (Boulenger, 1903) & line-spotted barb & Cyprinidae & $\mathrm{Z}$ & 3 & 4.4 & 4.6 & \\
\hline Bmot* & Barbus motebensis (Steindachner, 1894) & Marico barb & Cyprinidae & $\mathrm{ST} / \mathrm{E}$ & 3 & 3.0 & 3.1 & \\
\hline Bnee* & Barbus neefi (Greenwood, 1962) & sidespot barb & Cyprinidae & $\mathrm{Z}$ & 20 & 3.4 & 3.4 & $\mathrm{~B}$ \\
\hline Bpau & Barbus paludinosus (Peters, 1852) & straightfin barb & Cyprinidae & $\mathrm{Z}$ & 20 & 2.3 & 1.8 & \\
\hline Btri & Barbus trimaculatus (Peters, 1852) & threespot barb & Cyprinidae & $\mathrm{Z}$ & 23 & 2.7 & 1.8 & $\mathrm{~F}$ \\
\hline Buni & Barbus unitaeniatus (Günther, 1866) & longbeard barb & Cyprinidae & $\mathrm{Z}$ & 10 & 2.3 & 2.2 & $\mathrm{~F}$ \\
\hline Bviv & Barbus viviparus (Weber, 1897) & bowstripe barb & Cyprinidae & $\mathrm{Z}$ & 9 & 2.3 & 3 & $\mathrm{~F}$ \\
\hline Lcon & Labeo congoro (Peters, 1852) & purple labeo & Cyprinidae & $\mathrm{Z}$ & 5 & 3.3 & 3 & \\
\hline Lcyl & Labeo cylindricus (Peters, 1852) & redeye labeo & Cyprinidae & $\mathrm{Z}$ & 22 & 3.1 & 3.1 & $\mathrm{~F}$ \\
\hline Lmol & Labeo molybdinus (du Plessis, 1963) & leaden labeo & Cyprinidae & $\mathrm{Z}$ & 31 & 3.3 & 3.2 & E \\
\hline Lros & Labeo rosae (Steindachner, 1894) & rednose labeo & Cyprinidae & $\mathrm{Z}$ & 5 & 2.5 & 3 & \\
\hline Lmar & Labeobarbus marequensis (Smith, 1841) & largescale yellowfish & Cyprinidae & $\mathrm{Z}$ & 76 & 3.2 & 2.1 & $\mathrm{~F}$ \\
\hline Lpol & Labeobarbus polylepis (Boulenger, 1907) & smallscale yellowfish & Cyprinidae & $\mathrm{ST} / \mathrm{E}$ & 20 & 3.3 & 2.9 & \\
\hline Mbre & Mesobola brevianalis (Boulenger, 1908) & river sardine & Cyprinidae & $\mathrm{Z}$ & 10 & 1.1 & 2.8 & $\mathrm{~F}$ \\
\hline Oper* & $\begin{array}{l}\text { Opsaridium peringueyi (Gilchrist \& Thompson, } \\
\text { 1913) }\end{array}$ & southern barred minnow & Cyprinidae & $\mathrm{Z}$ & 8 & 4.9 & 4.4 & $\mathrm{E}$ \\
\hline Aura* & Amphilius uranoscopus (Pfeffer, 1889) & $\begin{array}{l}\text { stargazer (mountain } \\
\text { catfish) }\end{array}$ & Amphiliidae & Z & 21 & 4.8 & 4.8 & -- \\
\hline Sint & Schilbe intermedius (Rüppell, 1832) & silver catfish & Schilbeidae & $\mathrm{Z}$ & 3 & 1.3 & 1.8 & \\
\hline Cgar & Clarias gariepinus (Burchell, 1822) & sharptooth catfish & Clariidae & $\mathrm{Z}$ & 26 & 1.7 & 1 & \\
\hline Cpar & Chiloglanis paratus (Crass, 1960) & sawfin suckermouth & Mochokidae & $\mathrm{Z} / \mathrm{E}$ & 28 & 3.2 & 3.1 & $\mathrm{E}$ \\
\hline Cpre* & Chiloglanis pretoriae (Van der Horst, 1931) & shortspine suckermouth & Mochokidae & $\mathrm{Z}$ & 59 & 4.8 & 4.5 & $\mathrm{D}$ \\
\hline Cswi* & Chiloglanis swierstrai (Van der Horst, 1931) & lowveld suckermouth & Mochokidae & $\mathrm{Z}$ & 14 & 4.8 & 3.3 & $\mathrm{~F}$ \\
\hline Omos & Oreochromis mossambicus (Peters, 1852) & Mozambique tilapia & Cichlidae & $\mathrm{Z}$ & 28 & 0.9 & 1.3 & $\mathrm{~F}$ \\
\hline Pphi & Pseudocrenilabrus philander (Weber, 1897) & southern mouthbrooder & Cichlidae & $\mathrm{Z}$ & 66 & 1.0 & 1.4 & \\
\hline Tren & Tilapia rendalli (Boulenger, 1896) & redbreast tilapia & Cichlidae & $\mathrm{Z}$ & 8 & 1.8 & 2.1 & $\mathrm{~F}$ \\
\hline Tspa & Tilapia sparrmanii (Smith, 1840) & banded tilapia & Cichlidae & $\mathrm{Z}$ & 41 & 0.9 & 1.4 & $\mathrm{C}$ \\
\hline
\end{tabular}

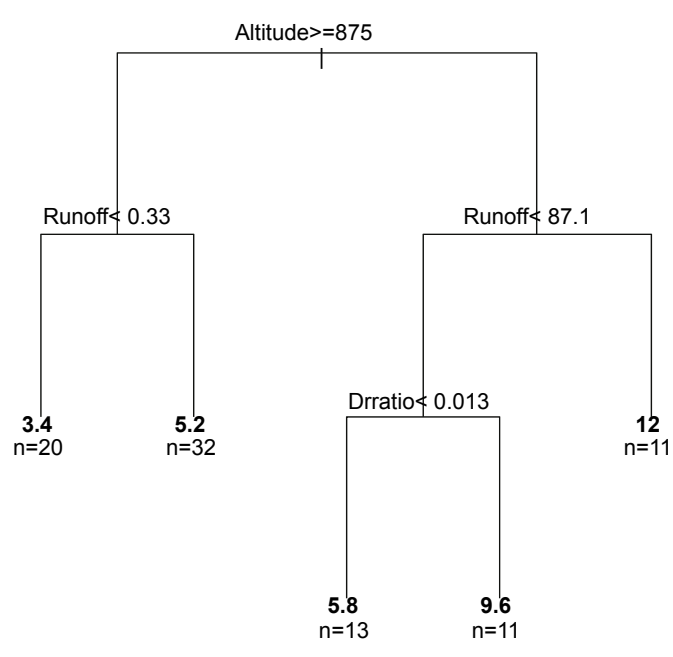

Figure 2

Regression tree for species richness, where branches represent splits based on the associated environmental condition (Table 1) - the left branch is selected when the stated threshold condition is true. Text for each 'leaf' shows mean species richness and the respective number of sites ( $n$ ) in that branch. goby), Labeo capensis (Orange River labeo), Labeo ruddi (silver labeo), Micropterus dolomieu (smallmouth bass), and Micropterus salmoides (largemouth bass), occurred at only one site. An additional 5 species, Cyprinus carpio (carp), Marcusenius macrolepidotus (Bulldog), Oncorhynchus mykiss (rainbow trout), Petrocephalus catostoma (Churchill), and Synodontis zambezensis (brown squeaker), occurred at only 2 sites. Five of these 13 fishes - mosquitofish, smallmouth and largemouth bass, carp, and rainbow trout - are not native to the Olifants catchment. The 29 fish species occurring at $>2$ sites are shown in Table 2. Subsequent analysis was conducted on these 29 species for 87 sites: 1 site contained only rainbow trout and was dropped.

Olifants River fish assemblages are dominated by minnows (family Cyprinidae), and by fishes of the Zambezian fauna. Four of the species are endemic to South Africa (Table 2, Skelton, 1993). The most widely distributed species was Labeobarbus marequensis, occurring at $76 \%$ of all sites, followed by Pseudocrenilabrus philander (66\%) and Chiloglanis pretoriae (59\%) (Table 2). The rest of the species occurred at fewer than half of the sites, and 14 of 29 occurred at fewer than $15 \%$ of the sites. Species tolerance scores for flow and physicochemical modification ranged widely (Table 2); these scores were highly 


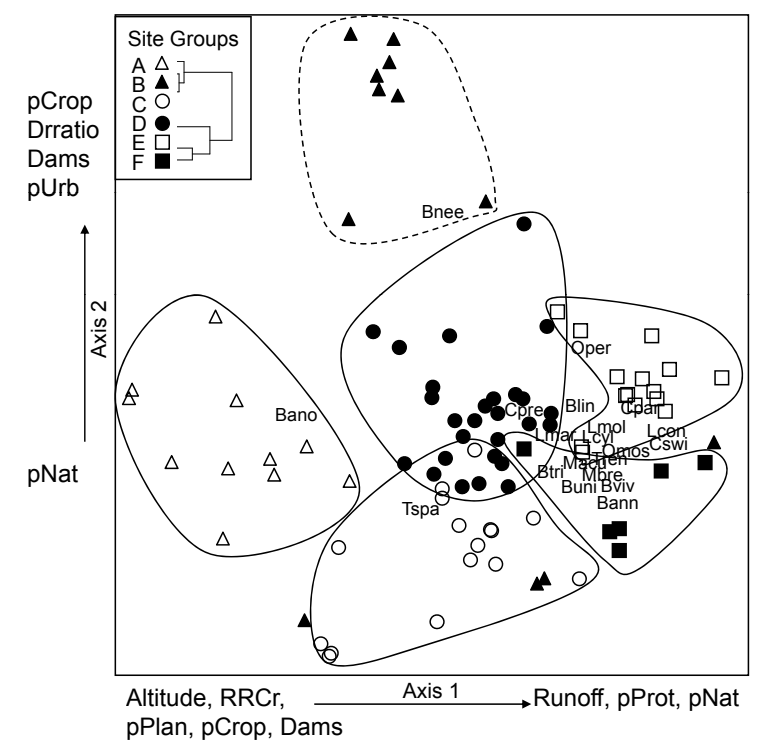

Figure 3

NMS ordination of 87 sites from the Olifants River catchment, based on their fish assemblage data. Symbols represent sites, and they are coded by cluster (cluster analysis dendrogram is shown in inset). Species that were significant indicators for a particular cluster are graphed based on weighted averaging (see Table 2 for species codes). Axis 1 explains $33 \%$ of the variance and Axis 2 explains $31 \%$ of the variance in this system. Environmental variables significantly related to these axes are also shown in this figure (see Table 1).

correlated with each other $(r=0.87, \mathrm{p}<0.0001)$, indicating that species tolerance is similar to these 2 different pressures.

The result of the NMS ordination of the sites by their fish assemblages is shown in Fig. 3. The ordination was significant in Monte Carlo analysis $(\mathrm{p}<0.01$ for three-dimensional solution); additional dimensions provided small reductions in stress. The solution had a final stress of 15.36 and instability of 0.00009 , which are reasonable values for NMS (McCune et al., 2002). The dominant gradient (Axis 1) explained $33 \%$ of the variance, and is most closely related to altitude (Table 1). This is consistent with the first split on the regression tree (Fig. 2), which was based on altitude. Axis 2 explained 31\% of the variance, and represented a gradient from high to low human influence (Fig. 3, Table 1).

Cluster analysis identified 6 site groups (Fig. 3 inset) that form distinct clusters on the ordination graph (Fig. 3). Groups A, $\mathrm{B}$, and $\mathrm{C}$ were closely related to each other according to the cluster analysis (Fig. 3 inset), but showed substantial distance from one another on the ordination graph, which indicated greater differences in assemblage structure among them. Groups A, B, and $\mathrm{C}$ corresponded with the high-altitude end of Axis 1; Group C plotted in a more negative direction on Axis 2, indicating higher impact. Group D plotted at the centre of Fig. 3, corresponding with mid-altitude. Groups E and F occurred at the positive end of Axis 1, corresponding to the low altitude. These groups are close to one another in ordination distance, so their assemblage structures are similar; however, Group F is located in a more negative position on Axis 2, corresponding with more human impact. MRPP indicated that the separation of the fish assemblages among the 6 site groups was highly significant $(p<0.0001)$.

Results from indicator species analysis in PC-ORD showed that one species was selected as an indicator for each of the 3 higher-altitude site Groups A-C (Table 2). Our classification tree analysis results showed that Barbus anoplus, the indicator
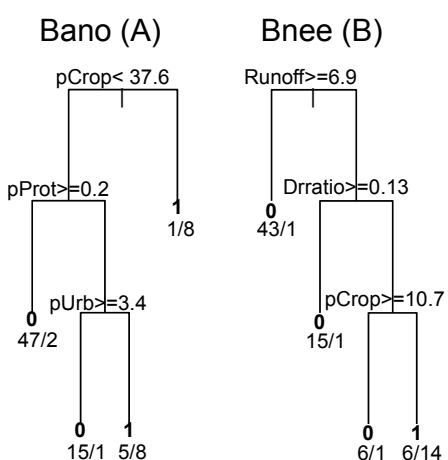

Tspa (C)

Cpre (D)
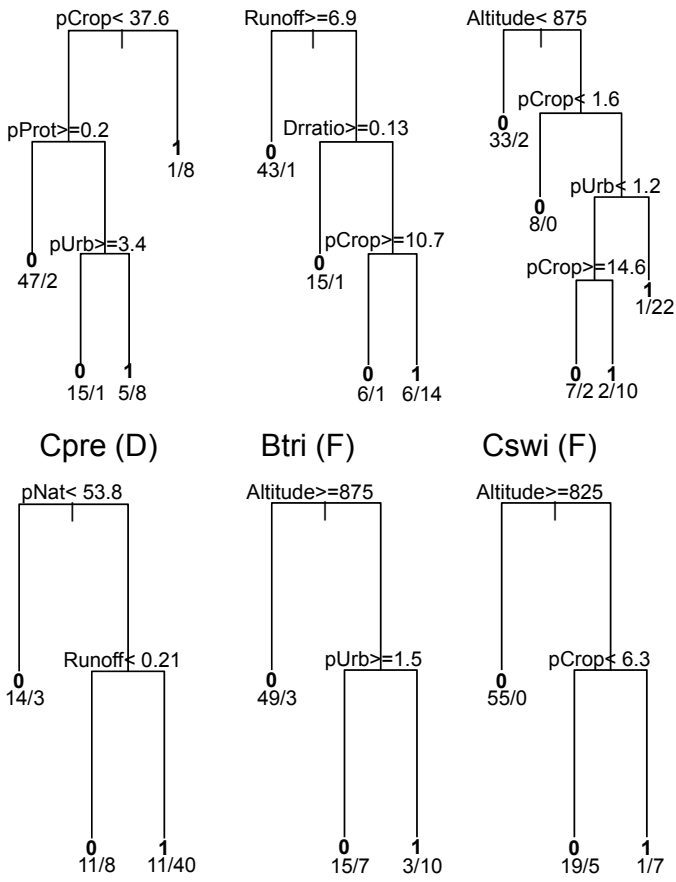

Cswi (F)

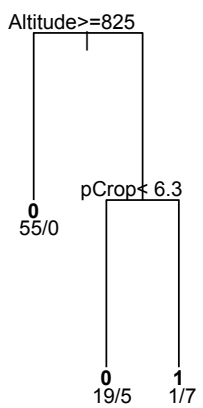

Figure 4

Classification tree diagrams for species from Table 2 that are indicators for the site groups in parentheses, where branches represent splits based on the associated environmental condition (see Table 1) and the left branch is selected when the stated threshold condition is true. Text for each 'leaf' indicates absence (0) or presence (1) and the number of sites where the species is absent/present for that branch.

for Group A, was found at sites with high cropland ( $>38 \%$ ), or at sites with a low percentage of protected area but also a low percentage of urban area (Fig. 4). The Group B indicator Barbus neefi occurred at sites with water runoff $>6.6 \mathrm{Mm}^{3} / \mathrm{a}$, with lower dam:runoff ratio and less than $11 \%$ cropland (Fig. 4). The Group C indicator Tilapia sparrmanii was found at high altitude sites $(>875 \mathrm{~m})$ where cropland was in the range of $2-15 \%$ and Urban was $>1 \%$ (Fig. 4 ). Thus, B. neefi occurred more often in less impacted sites, while $B$. anoplus and T. sparrmanii appeared to be favoured in cropland and mixed cropland/urban settings, respectively. The flow tolerance rating for these indicator species (Kleynhans, 2008) was consistent with the classification tree results, where the rating for $B$. neefi (3.4) indicated that this species was less tolerant than the other 2 indicator species B. anoplus (2.3) and T. sparrmanii (0.9). Physicochemical tolerance ratings followed a similar pattern: $B$. neefi (3.4) $>$ B. anoplus (2.6) $>$ T. sparrmanii (1.4). Thus, $B$. neefi is also less tolerant of flow and physicochemical modifications.

The single indicator species for the mid-altitude site Group D, C. pretoriae, was more likely to occur under conditions of high natural land cover ( $>53 \%$ ) and positive water runoff (>0.2 Mm $3 /$ a) (Fig. 4). The low-altitude Groups E and $F$ had 3 and 11 indicator species, respectively (Table 2). Seven species were too rare for significant trees to be developed; most of the other indicator species responded to altitude and/or runoff. The trees for Group E indicators Chiloglanis paratus and Labeo molybdinus showed a single split based on altitude (825 $\mathrm{m}$ and $925 \mathrm{~m}$, respectively), below which they were much more likely to be present. Trees for Group F indicators 
Oreochromis mossambicus and Labeo cylindricus were a single split based on runoff (57 and $76 \mathrm{Mm}^{3} / \mathrm{a}$, respectively), above which they were much more likely to be present. Similarly, Labeobarbus marequensis occurred at nearly all sites with higher runoff $\left(>0.33 \mathrm{Mm}^{3} / \mathrm{a}\right)$ and lower altitude $(<1175 \mathrm{~m})$. Barbus trimaculatus and Chiloglanis swierstrai were also found only at lower altitudes; $B$. trimaculatus was found in fewer urban areas $(<1.5 \%)$, while $C$. swierstrai was more likely to occur where dry-land cropland was $>6.3 \%$ (Fig. 4). Mean species tolerance ratings (Kleynhans, 2008) were significantly greater for Group $\mathrm{E}$ than for Group $\mathrm{F}$ for both modifications of flow (3.8 vs. 2.6, Wilcoxon 2-sample test $\mathrm{p}=0.0287$ ) and for modification of physicochemical conditions (3.6 vs. 2.5, Wilcoxon 2-sample test $\mathrm{p}=0.0343$ ).

\section{Discussion}

It is not surprising that altitude and position in the catchment were the most important variables in describing fish assemblage structure in the Olifants River catchment. A similar pattern was also found in other parts of Africa, including Zimbabwe (Kadye, 2008), Gabon (Ibanez et al., 2007), and the Ivory Coast (Koffi Konan et al., 2006). Altitude is a surrogate for many variables, including temperature, rainfall, soils, geology, and channel form. Rowntree et al. (2000) reported that the geology differs among the upper, middle, and lower sections of the catchment. WRC (2001) reports approximately a $6^{\circ} \mathrm{C}$ difference in mean temperatures between the upper and lower reaches of the Olifants catchment. This altitudinal gradient, and the turnover of species associated with it, is important because it suggests that no single umbrella species will provide coverage for the entire catchment (Hitt and Frissell, 2004). The only common species with a cosmopolitan distribution was Pseudocrenilabrus philander, which is recognised as a tolerant species (Kleynhans, 2008), and therefore not representative of all target species in the catchment (Hitt and Frissell, 2004).

In addition to the natural influence of altitude, our results showed that there is some impact of human activity in the Olifants. Dry-land crops and dams were the most significant pressures in this catchment; this finding is consistent with the assessment of the Water Research Commission (2001). Influences from dry-land crops include erosion and possible inputs of agrochemicals (DWAF, 2004; Ashton, 2007). Dams are widely recognised as significant influences on freshwater systems; major effects include altered timing and volume of flow, modification of habitat, and alteration of sediment, nutrient, and temperature regimes (Postel and Richter, 2003). However, Amis et al. (2007) noted that neither cropland nor dams were important predictors of instream integrity in north-western South Africa, so there are some differences across the catchments of South Africa that may be due to particular environmental settings of the catchments. We have used remotely sensed data in the analysis: additional pressures not represented here include alien vegetation and industrial discharges. Although none of the 5 alien species in the basin occurred at $>2$ sites, future increases in these species may have significant effects on certain components of the fish assemblage. For example, Gratwicke and Marshall (2001) found that the presence of exotic predators in streams around Harare, Zimbabwe, was related to a significant reduction of Barbus species, while other species were unaffected.

In the upper reaches of the Olifants catchment, we identified three distinct types of low-richness assemblages with large differences in species composition - essentially a species turnover. B. neefi appeared to be the dominant species in less impacted sites, while B. anoplus and T. sparrmanii appeared to be favoured in cropland and mixed cropland/urban settings, respectively. Thus, based on our analysis and due to its flow sensitivity, B. neefi may be a useful focal species for higher altitude streams. The range of 11 to $38 \%$ dry-land cropping represents a transition from $B$. neefi to $B$. anoplus. This species turnover is consistent with the Skukuza Statement (Skukuza Freshwater Group, 2006), which describes how freshwater ecological systems may cross thresholds into alternate community states from which recovery may be difficult or impossible. Although additional experimentation is needed to assess the stability of the different states (Beisner et al., 2003), the thresholds identified in the study could be used to guide the protection of smaller streams in the upper region of this catchment against the shift to an impaired state.

The desired ecological state for most of the upper region of the Olifants is fair (WRC, 2001), which is the current status for most of this area. Any restoration of instream habitat is unlikely to improve conditions unless there is a focus on the land-use practices that affect and sustain instream processes (Helfman, 2007). Because of the intense development pressure and natural resources demand in the upper Olifants, it is unlikely that the system will be restored above the status of fair. Therefore, the strategy for the Olifants could follow the proposals of Seastedt et al. (2008), who suggested that conservation efforts should focus less on restoring degraded ecosystems to their original state and more on sustaining current ecosystems so that they are resilient to further environmental change. Catchment management to support sustainable systems would encompass the active support of multiple stakeholders in order to create balance among economic, social, and ecosystem needs (Roux et al., 2006; Ashton, 2007).

Although the middle section of the Olifants catchment was not unique in terms of species, a single indicator species for this section, C. pretoriae, could be considered a focal species due to its status as an indicator for a particular site group (Table 2) and its preference for rivers with natural land and higher flows (Fig. 4). C. pretoriae was also suggested as a focal species by Roux et al. (2008) for the South African Lowveld region. This species has a limited range, although it does occur to the north of this catchment (Skelton, 1993). The scale of the Olifants may be appropriate for the management of $C$. pretoriae due to the species' local migration (Kleynhans, 2008) and the catchment's evolutionary history (Wishart and Davies, 2003). The desired ecological state for rivers in the middle region of Olifants is predominantly good, which in many cases represents an improvement over the present ecological state (WRC, 2001). Current conservation efforts in South Africa include the identification of specific river segments for protection (e.g., Nel et al., 2007). This analysis identified supporting habitats for C. pretoriae as those with the percent of natural land use and the water runoff above specified thresholds, so river segments with these characteristics should be conservation priorities.

In order to sustain protection of specific river segments, it is also necessary to protect the ecological processes that shape fish assemblages within these segments. For example, we can retain longitudinal connectivity to maintain the process of seasonal migration (Freeman et al., 2007). Connectivity also allows tributaries to serve as refugia for species (Nel et al., 2007). Thus, management of the middle reach of the Olifants catchment may focus on the conservation of $C$. pretoriae metapopulations, where the concept of metapopulation conser- 
vation extends protection across space and considers connectivity of supporting habitats (Baguette, 2004). Moilanen et al. (2008) showed that including connectivity in species distribution modelling had a major influence on the prioritisation of areas for conservation.

The finding of higher species richness at lower altitude sites with high runoff is consistent with the finding of Kleynhans (1999) for the Crocodile River. Our regression tree results show that for low-altitude sites, species richness increases with increased dam:runoff ratio, where increased dam pressure is associated with the addition of species to the assemblage. Kadye and Marshall (2007) hypothesised that a future dam on the Nyagui River in Zimbabwe would lead to a decrease in species that prefer fast water and an increase in cichlids and introduced species. Poff et al. (2007) found that across the United States, dams have increased the homogenisation of the flow regime, leading to conditions favouring the spread of cosmopolitan species in place of locally adapted biota. Our results did not indicate any loss of species with increasing dam pressures; rather, we observed more subtle shifts in assemblage structure - as evidenced by the close ordination distance in Fig. 3 - including the addition of species more tolerant of flow and physicochemical modifications. Thus, species richness on its own may not be an optimal measure for conservation planning; the densities of selected species that are less tolerant to flow alteration, or the ratios of such species to more tolerant species, may be better conservation measures.

The desired ecological state for the lower catchment of the Olifants ranges from fair to natural (WRC, 2001). Much of this area is protected within the Kruger National Park, which enhances the conservation of these assemblages. However, Roux et al. (2008) have concluded for the Kruger National Park that preserving downstream areas is not enough to protect biodiversity; upstream areas also need protection to ensure that sufficient water quality and appropriate flow timing and variability are available to support downstream biodiversity. To ensure a relatively natural flow regime and free movement of species, conservation strategies have to extend beyond designated protected areas to whole catchments (Roux et al., 2006).

Conservation efforts for the Olifants must also consider fish assemblages and biodiversity within the broader context of the region (Roux et al., 2002; Driver et al., 2005). In an analysis of riverine conservation in the South African Lowveld, Roux et al. (2008) concluded that the optimal set of planning units for protecting regional biodiversity would not include the Olifants, since neighbouring catchments possessed higher conservation value. Dudgeon et al. (2006) concluded that the long-term protection of freshwater biodiversity requires a mixture of strategies that include reserves for highvalue areas and species- or habitat-centred plans that reconcile conservation with water resource use for human-modified ecosystems. An ecosystem approach to management can be used to reconcile these alternative services and ensure sustainability in the Olifants (Jewitt, 2002). This will be necessary to maintain genetic diversity (Wishart and Davies, 2003), as well as the provisioning of goods and services essential to people in communities within the catchment (Skukuza Freshwater Group, 2006).

Rigorous and integrated conservation approaches are needed to inform catchment management in the face of competing demands for water use across South Africa (O'Keeffe and Davies, 1991; Ashton, 2007; Pollard et al., 2007). Biodiversity, assemblage patterns, and individual species patterns each represent different aspects of the aquatic resources within a catchment. Current freshwater conservation activities in South Africa already incorporate biodiversity and focal species (Roux et al., 2006; Roux et al., 2008). An understanding of the patterns of fish assemblages provides context for these activities and can support the identification of species and areas that require additional attention (Kleynhans, 1999; Angermeier and Winston, 1999). Our study identified distinct assemblages with different characteristics that should be considered functional units for conservation at the catchment scale. These indicators can complement those used at regional, national, and global scales; harmonising indicators across spatial scales is an important area for future research. A comprehensive conservation plan should include multiple conservation measures, as well as methods to combine measures across multiple habitats and scales.

\section{Acknowledgements}

We acknowledge support of the US Embassy Science Fellows Program through the US Department of State. Special thanks to Nikki Brajevich (U.S. Embassy Pretoria) and Peter J Ashton (CSIR); to Dan McGarvey (U.S. EPA) for a helpful review; and to two anonymous reviewers whose comments were extremely helpful. We also thank Helen Dallas (UCT) for her kind help with the rivers database. Although this work was reviewed by US EPA and approved for publication, it may not necessarily reflect official Agency policy.

\section{References}

ABELL R (2002) Conservation biology for the biodiversity crisis: a freshwater follow-up. Conserv. Biol. 16 (5) 1435-1437.

AMIS MA, ROUGET M, BALMFORD A, THUILLER W, KLEYNHANS CJ, DAY J and NEL J (2007) Predicting freshwater habitat integrity using land-use surrogates. Water SA 33 (2) 215-221.

ANGERMEIER PL and WINSTON MR (1999) Characterizing fish community diversity across Virginia landscapes: Prerequisite for conservation. Ecol. Appl. 9 (1) 335-349.

ASHTON PJ (2007) Riverine biodiversity conservation in South Africa: current situation and future prospects. Aquat. Conserv.: Mar. Freshwater Ecosyst. 17 441-445.

BAGUETTE M (2004) The classical metapopulation theory and the real, natural world: a critical appraisal. Basic Appl. Ecol. 5 213-224.

BEISNER BE, HAYDON DT and CUDDINGTON K (2003) Alternative stable states in ecology. Front Ecol. Environ. 1 (7) 376-382.

CATO TM and O'DOHERTY G (1999) On the use of surrogate species in conservation biology. Conserv. Biol. 13 (4) 805-814.

DALLAS H, MOLTENO A, EWART-SMITH J and JANSSENS P (2007) Rivers Database Version 3: User Manual. Report for the Department of Water Affairs and Forestry River Health Programme. Prepared by The Freshwater Consulting Group in association with Soft Craft Systems. 71 pp.

DEPARTMENT OF WATER AFFAIRS AND FORESTRY (2004) Olifants Water Management Area: Internal Strategic Perspective. Prepared by GMKS, Tlou and Matji and WMB on behalf of the Directorate: National Water Resource Planning. DWAF Report No. P WMA 04/000/00/0304. Pretoria, South Africa.

DRIVER A, MAZE K, ROUGET M, LOMBARD AT, NEL J, TURPIE JK, COWLING RM, DESMET P, GOODMAN P, HARRIS J, JONAS Z, REYERS B, SINK K and STRAUSS T (2005) National spatial biodiversity assessment 2004: priorities for biodiversity conservation in South Africa. Strelitzia 17. South African National Biodiversity Institute, Pretoria, South Africa.

DUDGEON D, ARTHINGTON AH, GESSNER MO, KAWABATA ZI, KNOWLER DJ, LÉVÊQUE C, NAIMAN RJ, PRIEUR-RICHARD AH, SOTO D, STIASSNY MLJ and SULLIVAN CA (2006) Freshwater biodiversity: importance, threats, status and conservation challenges. Biol. Rev. 81 163-182. 
DUFRÊNE M and LEGENDRE P (1997) Species assemblages and indicator species: the need for a flexible asymmetrical approach. Ecol. Monogr. 67 345-366.

FREEMAN MC, PRINGLE CM and JACKSON CR (2007) Hydrological connectivity and the contribution of stream headwaters to ecological integrity at regional scales. JAWRA 43 5-14.

GRATWICKE B and MARSHALL BE (2001) The relationship between exotic predators Micropteris salmoides and Serranochromis robustus and native stream fishes in Zimbabwe. J. Fish Biol. 58 68-75.

HIGGINS JV, BRYER MT, KHOURY ML and FITZHUGH TW (2005) A freshwater classification approach for biodiversity conservation planning. Conserv. Biol. 19 432-445.

HELFMAN GS (2007) Fish Conservation: A Guide to Understanding and Restoring Global Aquatic Biodiversity and Fishery Resources. Island Press, Washington, USA.

HITT NP and FRISSELL CA (2004) A case study of surrogate species in aquatic conservation planning. Aquat. Conserv.: Mar. Freshwater Ecosyst. 14 625-633.

IBANEZ C, OBERDORFF T, TEUGELS G, MAMONONEKENE V, LAVOUÉ S, FERMON Y, PAUGY D, and TOHAM AK (2007) Fish assemblages structure and function along environmental gradients in rivers of Gabon (Africa). Ecol. Freshwater Fish $\mathbf{1 6}$ 315-334.

JEWITT G (2002) Can integrated water resources management sustain the provision of ecosystem goods and services? Phys. Chem. Earth 27 887-895.

JEWITT GPW, HERITAGE GL, WEEKS DC, MACKENZIE JA, VAN NIEKERK A, GORGENS AHM, O'KEEFFE J, ROGERS K and HORN M (1998) Modelling Abiotic-Biotic Links in the Sabie River. WRC Report No. 777/1/98. Report to the Water Research Commission, Pretoria, South Africa.

KADYE WT (2008) The application of a Fish Assemblage Integrity Index (FAII) in a Southern African river system. Water $S A 34$ 25-32.

KADYE WT and MARSHALL BE (2007) Habitat diversity and fish assemblages in an African river basin (Nyagui River, Zimbabwe) Afr. J. Ecol. 45 (3) 374-381.

KLEYNHANS CJ (1999) The development of a fish index to assess the biological integrity of South African rivers. Water SA 25 (3) 265-278.

KLEYNHANS CJ (2008) In: River Ecoclassification: Manual for Ecostatus Determination (Version 2) Module D: Volume 1 Fish Response Assessment Index (FRAI). Joint DWAF and WRC Report No. TT 330/08. Water Research Commission and Department of Water Affairs and Forestry, Pretoria, South Africa.

KOFFI KONAN F, LEPRIEUR F, OUATTARA A, BROSSE S, GRENOUILLET G, GOURÈNE G, WINTERTON P and LEK S (2006) Spatio-temporal patterns of fish assemblages in coastal West African rivers: a self-organizing map approach. Aquat. Living Resour. 19 361-370.

LANGDON R (2001) A preliminary index of biological integrity for fish assemblages of small coldwater stream in Vermont. Northeastern Naturalist 8 219-232.

LÉVÊQUE C (1997) Biodiversity Dynamics and Conservation: The Freshwater Fish of Tropical Africa. Cambridge University Press, Cambridge, United Kingdom.

LINDENMAYER DB, FISCHER J, FELTON A, MONTAGUEDRAKE R, MANNING AD, SIMBERLOFF D, YOUNGENTOB K, SAUNDERS D, WILSON D, FELTON AM, BLACKMORE C, LOWE A, BOND S, MUNRO N and ELLIOTT CP (2007) The complementarity of single species and ecosystem-oriented research in conservation research. Oikos 116 1220-1226.

MATTHEWS WJ (1998) Patterns in Freshwater Fish Ecology. Chapman and Hall, New York. 757 pp.

McCUNE B and MEDFORD MJ (1999) PC-Ord Software Version 4.10: Multivariate Analysis of Ecological Data. MJM Software Design, Gleneden Beach, Oregon. 237 pp.

McCUNE B, GRACE JB and URBAN DL (2002) Analysis of Ecological Communities. MJM Software Design, Gleneden Beach, Oregon. 300 pp.

MOILANEN A, LEATHWICK J and ELITH J (2008) A method for spatial freshwater conservation prioritization. Freshwater Biol. $\mathbf{5 3}$ 577-592.

NEL JL, ROUX D, GAREE G, KLEYNHANS CJ, MOOLMAN J, REYERS B, ROUGET M and COWLING RM (2007) Rivers in peril inside and outside protected areas: a systematic approach to conservation assessment of river ecosystems. Diversity \& Distrib. 13 341-352.

NOVOTNY V, BARTOŠOVÁ A, O'REILLY N and EHLINGER T (2005) Unlocking the relationship of biotic integrity of impaired waters to anthropogenic stresses. Water Res. 39 184-198.

O'KEEFFE J and DAVIES BR (1991) Conservation and management of the rivers of Kruger National Park: Suggested methods for calculating instream flow needs. Aquat. Conserv. 1 55-71.

POFF NL, OLDEN JD, MERRITT DM and PEPIN DM (2007) Homogenization of regional river dynamics by dams and global biodiversity implications. Proc. Nat. Acad. Sci. 104 (14) 5732-5737.

POLLARD SR, DU TOIT D, REDDY Y and TLOU T (2007) Guidelines for the Development of Catchment Management Strategies: Towards Equity, Efficiency and Sustainability in Water Resources Management. Department of Water Affairs and Forestry, Pretoria, South Africa.

POSTEL S and RICHTER B (2003) Rivers for Life. Island Press, Washington, USA.

RIVERS-MOORE NA, GOODMAN PS and NKOSI MR (2007) An assessment of the freshwater natural capital in KwaZulu-Natal for conservation planning. Water SA 33 (5) 665-674.

ROUX D, DE MOOR F, CAMBRAY J and BARBER-JAMES H (2002) Use of landscape-level river signatures in conservation planning: a South African case study. Conserv. Ecol. 6 (2) 6.

ROUX DJ, NEL JL, ASHTON PJ, DEACON AR, DE MOOR FC, HARDWICK D, HILL L, KLEYNHANS CJ, MAREE GA, MOOLMAN J and SCHOLES RJ (2008) Designing protected areas to conserve riverine biodiversity: Lessons from a hypothetical redesign of the Kruger National Park. Biol. Conserv. 141 100-117.

ROUX DJ, NEL JL, MACKAY HM and ASHTON PJ (2006) CrossSector Policy Objectives for Conserving South Africa's Inland Water Biodiversity. WRC Report No. TT 276/06. Water Research Commission, Pretoria, South Africa.

ROWNTREE KM, WADESON RA and O'KEEFFE J (2000) The development of a geomorphological classification system for the longitudinal zonation of South African rivers. S. Afr. Geogr. J. 82 (8) 163-172

SEASTEDT TR, HOBBS RJ and SUDING KN (2008) Management of novel ecosystems: Are novel approaches required? Front Ecol. Environ. 6 (10) 547-553.

SKELTON P (1993) A Complete Guide to the Freshwater Fishes of South Africa. Southern Book Publishers, Halfway House, South Africa. 388 pp.

SKELTON PH, CAMBRAY JA, LOMPARD A and BENN GA (1995) Patterns of distribution and conservation status of freshwater fishes in South Africa. S.Afr. J. Zool. 30 (3) 71-81.

THE SKUKUZA FRESHWATER GROUP (2006) The Skukuza Statement. Kruger National Park, South Africa (http://www.waternet. co.za/rivercons/docs/skuk06b symposium statement final.pdf).

THERNEAU TM and ATKINSON B (2008) RPART: Recursive Partitioning. $R$ Package Version 3.1-41. Report by Brian Ripley. URL: http://mayoresearch.mayo.edu/mayo/research/biostat/splusfunctions.cfm

THIEME ML, ABELL R, STIASSNY MLJ, SKELTON P, LEHNER B, TEUGELS GG, DINERSTEIN E, TOHAM AK, BURGESS $\mathrm{N}$ and OLSON D (2005) Freshwater Ecoregions of Africa and Madagascar. Island Press, Washington. 483 pp.

WATER RESEARCH COMMISSION (2001) State of the Rivers Report: Crocodile, Sabie-Sand \& Olifants River Systems. WRC Report No. TT 147/01. Water Research Commission, Pretoria, South Africa.

WISHART MJ (2000) Catchments as conservation units for riverine biodiversity. Afr. J. Aquat. Sci. 25 169-174.

WISHART MJ and DAVIES BR (2003) Beyond catchment considerations in the conservation of lotic biodiversity. Aquat. Conserv: Mar. Freshwater Ecosyst. 13 429-437. 